

Original Research Article

https://doi.org/10.20546/ijcmas.2017.608.064

\title{
Genetic Variability Analysis for Grain Yield and its Components Traits in Traditional Rice Varieties (TRVs)
}

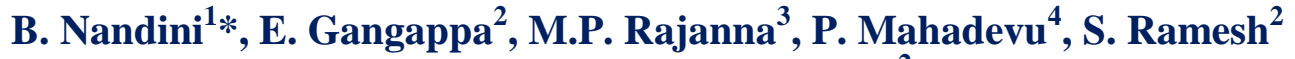 \\ and P.V. Shailaja Hittalmani ${ }^{2}$ \\ ${ }^{1}$ Seed Unit, UAS, Dharwad-580005, India \\ ${ }^{2}$ Department of Genetics and Plant Breeding, UAS, GKVK, Bangalore -560065, India \\ ${ }^{3}$ Zonal Agricultural Research Station, V.C. Farm, Mandya, India \\ ${ }^{4}$ Department of Genetics and Plant Breeding, College of Agriculture, Mandya, India \\ *Corresponding author
}

\begin{tabular}{|c|c|}
\hline & A B S T R A C T \\
\hline & \multirow{6}{*}{$\begin{array}{l}\text { Three hundred and twenty four Traditional Rice Varieties (TRVs) were collected from } \\
\text { different parts of Karnataka and were evaluated for grain yield and its attributes in two } \\
\text { seasons (kharif } 2011 \text { and summer 2012) at ZARS, VC Farm, Mandya, Karnataka, India. } \\
\text { The } 14 \text { quantitative traits studied were categorized into growth traits (days to } 50 \% \\
\text { flowering, Plant height, Productive and tillers plant }{ }^{-1} \text { ), panicle traits (panicle length, } \\
\text { spikelet panicle }{ }^{-1} \text {, chaffy panicle }{ }^{-1} \text { and spikelet fertility), grain quality traits (grain length, } \\
\text { grain breadth and L/B ratio) and grain yield traits ( } 1000 \text { grain weight, straw yield plant }{ }^{-1} \text {, } \\
\text { harvest index and grain yield plant }{ }^{-1} \text { ). Substantial variability among the accessions for } \\
\text { quantitative traits was recorded. The variability parameters such as mean, range, } \\
\text { standardized range, PCV, GCV, } \mathrm{h}^{2}(\text { bs) and genetic advance in TRVs were estimated. The } \\
\text { pattern of genetic diversity was estimated using model based K means clustering approach } \\
\text { statistics and formed four distinct clusters. The quantitative traits means and variances } \\
\text { differed significantly among the clusters. Cluster I comprised of the maximum number of } \\
\text { TRVs (137) and cluster IV consisted of } 21 \text { TRVs. The cluster IV followed by cluster II } \\
\text { contributed maximum mean values for many traits. These results are discussed in relation } \\
\text { to suitable strategies to be adopted for breeding rice varieties for increased productivity. }\end{array}$} \\
\hline Keywords & \\
\hline $\begin{array}{l}\text { GCV, PCV, } \\
\text { Genetic advance } \\
\text { and K means } \\
\text { cluster. }\end{array}$ & \\
\hline Article Info & \\
\hline $\begin{array}{l}\text { Accepted: } \\
\text { 04 June } 2017 \\
\text { Available Online: } \\
10 \text { August } 2017\end{array}$ & \\
\hline & \\
\hline
\end{tabular}

\section{Introduction}

Traditional Rice Varieties (TRVs) are an important component of crop genetic resources and are valued by rice breeders and farmers because of diversity, rarity and adaptability (Brush and Meng, 1998; FAO, 1998; Smale, 2006 and Gauchan et al., 2006). TRVs are often highly variable in appearance, but they are each identifiable morphologically and have a certain genetic integrity. Farmers assign them local names based on their distinct properties or particular characteristics as each TRVs has a reputation for adaptation to specific ecosystem. Hence farmers and researchers throughout the world continue to maintain and manage these TRVs within their production systems (FAO, 2010). Yet, their complete genetic potential has not yet been exploited in crop breeding programme (Gyawali et al., 2010). 
Undeniably, the success of green revolution has resulted in gradual erosion of genetic diversity of many crops, including rice, due to the replacement of TRVs with modern high-yielding cultivars. Owing to their adaptation to a wide range of agroecological conditions, TRVs provides tremendous genetic variability not found in modern varieties (Hanamaratti et al., 2008). Increased use of TRVs in crop breeding programmes would help enhance genetic base of cultivars whose cultivation significantly contribute to stable and sustainable production. Under these premises, TRVs were collected from different locations and conserved at Zonal Agricultural Research Station (ZARS), Mandya, India. As a prelude to their use in breeding programmes variability among TRVs was assessed for traits of economic importance and the results obtained are reported in this article.

\section{Materials and Methods}

A collection of $225 \mathrm{TRVs}$ constituted the material for the study. TRVs collected from different regions of southern Karnataka and maintained at AICRP on rice at ZARS, V.C. Farm, Mandya, Karnataka, India. The TRVs were sown following 15 x 15 Simple Lattice Design with two replications during kharif 2011 and summer 2012 at ZARS, Mandya, India. Each entry was sown in four rows each of $1.0 \mathrm{~m}$ length with spacing of a $0.3 \mathrm{~m}$ between rows and $0.20 \mathrm{~m}$ between plants within a row. All the recommended agronomic practices were followed during crop growth period to raise a healthy crop.

Observations were recorded on five plants selected at random from each entry in each replication for 14 metric traits. For the sake of convenience, the metric traits were classified into four sub groups such as (i) growth traits (days to 50\% flowering, plant height and productive tillers par plant) (i i ) panicle traits (panicle length, spikelets panicle $^{-1}$, chaffy spikelet panicle ${ }^{-1}$ and spikelet fertility) (iii) grain quality traits (grain length, grain breadth and L/B ratio) and (iv) yield traits (1000 grain weight, straw yield plant ${ }^{-1}$, harvest index and grain yield plant $^{-1}$ ). The mean of five plants for each metric trait was considered for statistical analysis. Descriptive statistics such as range and variance and their standardized values - Standardized range [(Maximum-Minimum/Mean ×100)], Phenotypic coefficient of variance (PCV), genotypic coefficient of variance (GCV), heritability and genetic advance were estimated (Snedecor and Cochram, 1994) to quantify variability and compare across traits.

The TRVs were grouped into four cluster using K means model (Macqueen, 1967) based clustering approach. The metric traits mean and variances among TRVs included in each cluster were estimated. The significance of trait means and variance among the four clusters was examined following ' $F$ ' and Levene (1960) tests, respectively.

\section{Results and Discussion}

Pooled analysis of variance for 14 metric traits (Table 1) revealed significant differences among the TRVs for all the traits indicating the existence of ample variability among the TRVs all the traits.

\section{Components of variability, heritability and genetic advance}

Presence of genetic variability per se is of less significance in crop breeding programmes. Knowledge on relative contribution of genetic and non-genetic sources on the quantitative trait variability is useful in formulating appropriate selection strategies to breed improved rice varieties. The estimates of standardized range provide clues about the 
occurrence of accessions with extreme expression which varied with the trait. However, standardized range per se does not reflect variability in the expression of all the accessions. The estimates of GCV and PCV which reflect average inter-accession differences are more useful statistics to understand variability among the germplasm accessions.

A higher PCV than GCV with narrow difference between them indicated a limited role of seasonal variation in the expression of most of the traits in TRVs (Table 2). High heritability coupled with high genetic advance indicated the effectiveness of selection for days to $50 \%$ flowering, grain length, grain breadth L/B ratio and straw yield palnt ${ }^{-1}$ (Mall et al., 2005, Ganapathy et al., 2007 and Karim et al., 2007).

The traits such as chaffy spikelet panicle ${ }^{-1}$, straw yield plant $^{-1}$ and grain yield plant ${ }^{-1}$ exhibited low heritability with moderate genetic advance, indicating possible role of non-additive gene effects in the inheritance of these characters. Hence, simple selection for these characters would be less effective. The response to selection for traits such as days to $50 \%$ flowering, productive tillers plant ${ }^{-1}, \mathrm{~L} / \mathrm{B}$ ratio and 1000 grain weight with high genotypic variance, high heritability coupled with high expected genetic gain would be encouraging.

\section{Variability analysis}

The efficiency and pace of rice genetic improvement programmes hinges on the precise information on magnitude of fixable (additive and additive based epitasis) component of genetic variability, $\mathrm{g} \times \mathrm{e}$ (both spatial and temporal) interaction, and DNA marker-assisted chromosomal localization and mode of action of genes controlling traits of economic importance. The identification of accessions contrasting for traits of economic importance is a prerequisite for eliciting such information. Cluster analysis helps in grouping of accessions sharing similar characters in different clusters and to identify genetically diverse and desirable genotypes.

The information of genetic variability per se is not of much utility in crop breeding programmes. The organization of variability in terms of grouping TRVs based on their similarity and dissimilarity would help to choose the potential parents for hybridization and to obtain useful segregants.

The mean expression of growth traits such as days to $50 \%$ flowering, plant height and productive tillers plant ${ }^{-1}$ of TRVs included in clusters I and IV was highest. Among panicle traits, means of TRVs included in cluster II followed by cluster IV was higher (Tables 3 and 4). A higher mean value was noticed for grain quality of TRVs included in cluster III followed by cluster II was better than that in other cluster. The grain yield potential of TRVs included in cluster IV was better than those included in other clusters. Effecting crosses among the TRVs of cluster II and cluster IV is expected to recover genotypes with combination of desired traits.

\section{Traits-specific accessions}

Exploitation of natural genetic variability help meet short-term objectives as very often breeders are forced to meet immediate requirement of the farmers, consumers and end-users. Continued crop genetic improvement to meet medium- and/long-term requirements requires availability of variability induced through deliberately planned crosses among the genotypes harbouring desired combination of traits. Evaluation of germplasm provides information about the accessions/genotypes with desired combination of traits. 
Table.1 Pooled analysis of variance for grain yield and its component traits in Traditional Rice Varieties

\begin{tabular}{|l|l|l|l|l|l|l|l|l|}
\hline Source of variation & df & $\begin{array}{l}\text { Days to 50\% } \\
\text { flowering }\end{array}$ & $\begin{array}{l}\text { Plant height } \\
(\mathrm{cm})\end{array}$ & $\begin{array}{l}\text { Panicle } \\
\text { length } \\
(\mathrm{cm})\end{array}$ & $\begin{array}{l}\text { Productive } \\
\text { tillers plant }\end{array}$ & $\begin{array}{l}\text { Spikelet's } \\
\text { panicle }^{-1}\end{array}$ & $\begin{array}{l}\text { Chaffy } \\
\text { panicle }\end{array}$ \\
\hline Replications & 1 & 6.74 & 139.80 & 12.44 & 7.57 & 463.77 & 347.46 \\
\hline TRVs & 224 & 298.25 & 477.90 & 6.56 & 7.36 & 1440.50 & 138.14 & 78.30 \\
\hline Seasons & 1 & 6977.81 & 11154.18 & 145.30 & 1136.81 & 20579.08 & 56368.89 & 45185.68 \\
\hline TRVs $\times$ Seasons & 224 & 209.12 & 231.29 & 1.73 & 5.30 & 212.53 & 128.12 & 85.42 \\
\hline Error & 448 & 4.76 & 103.75 & 2.06 & 2.14 & 214.90 & 76.62 & 47.15 \\
\hline Total & 899 & & & & & & & \\
\hline
\end{tabular}

* Significant @ $\mathrm{P}=0.05$

** Significant @ P=0.01

Table 1: Contd...

\begin{tabular}{|c|c|c|c|c|c|c|c|c|}
\hline Source of variation & Df & $\begin{array}{ll}1000 & \text { grain } \\
\text { weight }(\mathrm{g}) & \\
\end{array}$ & $\begin{array}{l}\text { Grain } \\
\text { length } \\
(\mathrm{mm}) \\
\end{array}$ & $\begin{array}{l}\text { Grain } \\
\text { breadth } \\
(\mathrm{mm})\end{array}$ & $\begin{array}{l}\mathrm{L} / \mathrm{B} \\
\text { ratio }\end{array}$ & $\begin{array}{l}\text { Straw } \\
\text { yield } \\
\text { plant }^{-1}(\mathrm{~g})\end{array}$ & $\begin{array}{l}\text { Harvest } \\
\text { index }\end{array}$ & $\begin{array}{l}\text { Grain yield } \\
\text { plant }^{-1}(\%)\end{array}$ \\
\hline Replications & 1 & 15.36 & 0.27 & 0.00 & 0.11 & 598.33 & 0.07 & 35.89 \\
\hline Seasons & 1 & 336.05 & 0.00 & 0.01 & 0.12 & 6312.52 & 0.65 & 1065.94 \\
\hline TRVs $\times$ Seasons & 224 & 9.57 & 0.22 & 0.01 & 0.11 & 27.76 & 0.01 & 29.30 \\
\hline
\end{tabular}


Table.2 Estimates of descriptive statistics and components of variability for grain yield and its component traits of Traditional Rice Varieties

\begin{tabular}{|c|c|c|c|c|c|c|c|c|c|}
\hline \multirow{2}{*}{ Classification } & \multirow{2}{*}{ Traits } & \multirow{2}{*}{ Mean $\pm \mathrm{SE}$} & \multicolumn{2}{|l|}{ Range } & \multirow{2}{*}{$\begin{array}{l}\text { Standardized } \\
\text { range }\end{array}$} & \multicolumn{2}{|c|}{$\begin{array}{l}\text { Coefficient of } \\
\text { variability }\end{array}$} & \multirow{2}{*}{$\begin{array}{l}\text { Broad sense } \\
\text { heritability } \\
(\%)\end{array}$} & \multirow{2}{*}{$\begin{array}{l}\text { Genetic } \\
\text { Advance as } \\
\text { per cent of } \\
\text { mean }\end{array}$} \\
\hline & & & Lowest & Highest & & GCV & PCV & & \\
\hline \multirow{3}{*}{ Growth traits } & Days to $50 \%$ flowering & $90.80 \pm 0.57$ & 71.75 & 115.75 & 0.48 & 9.42 & 9.59 & 96.53 & 19.07 \\
\hline & Plant height $(\mathrm{cm})$ & $120.28 \pm 0.72$ & 83.28 & 148.81 & 0.54 & 7.95 & 10.10 & 61.88 & 12.88 \\
\hline & Productive tillers plant $^{-1}$ & $8.75 \pm 0.09$ & 5.36 & 14.98 & 1.10 & 13.43 & 17.33 & 60.05 & 21.44 \\
\hline \multirow{4}{*}{ Panicle traits } & Panicle length $(\mathrm{cm})$ & $23.09 \pm 0.08$ & 18.80 & 27.35 & 0.37 & 4.75 & 6.24 & 57.79 & 7.43 \\
\hline & Spikelet panicle $^{-1}$ & $128.23 \pm 1.26$ & 74.25 & 194.92 & 0.94 & 13.58 & 15.92 & 72.81 & 23.88 \\
\hline & Chaffy panicle ${ }^{-1}$ & $28.23 \pm 0.39$ & 11.00 & 47.83 & 1.30 & 13.57 & 26.12 & 26.98 & 14.52 \\
\hline & Spikelet fertility $(\%)$ & $77.48 \pm 0.29$ & 59.58 & 87.83 & 0.36 & 3.49 & 7.28 & 22.92 & 3.44 \\
\hline \multirow{3}{*}{$\begin{array}{l}\text { Grain quality } \\
\text { traits }\end{array}$} & Grain length $(\mathrm{mm})$ & $8.02 \pm 0.07$ & 4.14 & 11.24 & 0.88 & 14.82 & 15.07 & 96.72 & 30.02 \\
\hline & Grain breadth (mm) & $2.58 \pm 0.02$ & 1.74 & 3.45 & 0.66 & 16.15 & 16.29 & 98.27 & 32.99 \\
\hline & $\mathrm{L} / \mathrm{B}$ ratio & $3.19 \pm 0.05$ & 1.32 & 5.78 & 1.40 & 23.89 & 24.07 & 98.49 & 48.84 \\
\hline \multirow{4}{*}{ Yield traits } & 1000 grain weight $(\mathrm{g})$ & $23.09 \pm 0.19$ & 14.87 & 30.28 & 0.67 & 11.29 & 14.27 & 62.50 & 18.38 \\
\hline & Straw yield plant $^{-1}(\mathrm{~g})$ & $15.29 \pm 0.19$ & 8.85 & 27.03 & 1.19 & 13.72 & 23.00 & 35.58 & 16.86 \\
\hline & Harvest index & $0.48 \pm 0.01$ & 0.33 & 0.66 & 0.68 & 9.60 & 15.34 & 39.20 & 12.38 \\
\hline & Grain yield plant $^{-1}(\mathrm{~g})$ & $14.04 \pm 0.17$ & 6.94 & 20.75 & 0.98 & 13.54 & 22.29 & 36.87 & 16.93 \\
\hline
\end{tabular}


Table.3 Estimates of traits means among Traditional Rice Varieties classified into different clusters

\begin{tabular}{|c|c|c|c|c|c|c|c|}
\hline \multirow{3}{*}{ Classification } & \multirow{2}{*}{ Traits } & \multicolumn{4}{|c|}{ Mean of Clusters } & \multirow{3}{*}{ 'F' Statistics } & \multirow{3}{*}{ Probability } \\
\hline & & $\mathrm{C1}$ & $\mathrm{C2}$ & $\mathbf{C 3}$ & $\mathbf{C 4}$ & & \\
\hline & Size of cluster & 137 & 41 & 26 & 21 & & \\
\hline \multirow{3}{*}{ Growth traits } & Days to $50 \%$ flowering & 91.72 & 89.84 & 87.54 & 91.08 & 1.93 & 0.13 \\
\hline & Plant height $(\mathrm{cm})$ & 122.04 & 123.32 & 99.55 & 127.47 & 61.74 & $<.0001$ \\
\hline & Productive tillers plant $^{-1}$ & 8.77 & 8.83 & 9.90 & 8.41 & 2.09 & 0.10 \\
\hline \multirow{4}{*}{ Panicle traits } & Panicle length $(\mathrm{cm})$ & 23.13 & 23.45 & 22.04 & 23.31 & 7.34 & 0.00 \\
\hline & Spikelet panicle $^{-1}$ & 130.93 & 103.90 & 118.96 & 168.54 & 225.14 & $<.0001$ \\
\hline & Chaffy panicle $^{-1}$ & 28.96 & 23.24 & 28.30 & 33.72 & 21.01 & $<.0001$ \\
\hline & Spikelet fertility (\%) & 77.37 & 77.49 & 76.04 & 79.47 & 2.31 & 0.08 \\
\hline \multirow{3}{*}{$\begin{array}{l}\text { Grain quality } \\
\text { traits }\end{array}$} & Grain length (mm) & 7.88 & 8.26 & 8.30 & 8.13 & 1.72 & 0.16 \\
\hline & Grain breadth (mm) & 2.65 & 2.58 & 2.42 & 2.44 & 3.16 & 0.03 \\
\hline & $\mathrm{L} / \mathrm{B}$ ratio & 3.05 & 3.31 & 3.63 & 3.47 & 6.04 & 0.00 \\
\hline \multirow{4}{*}{ Yield traits } & 1000 grain weight $(\mathrm{g})$ & 23.38 & 22.95 & 21.44 & 23.56 & 3.37 & 0.02 \\
\hline & Straw yield plant $^{-1}(\mathrm{~g})$ & 15.41 & 15.58 & 13.67 & 15.85 & 3.26 & 0.02 \\
\hline & Harvest index & 0.48 & 0.49 & 0.59 & 0.49 & 3.04 & 0.03 \\
\hline & Grain yield plant $^{-1}(\mathrm{~g})$ & 13.99 & 14.44 & 13.59 & 14.36 & 0.70 & 0.55 \\
\hline
\end{tabular}


Table.4 Estimates of traits variances among Traditional Rice Varieties classified into different clusters

\begin{tabular}{|c|c|c|c|c|c|c|c|}
\hline \multirow{3}{*}{ Classification } & \multirow{2}{*}{ Traits } & \multicolumn{4}{|c|}{ Variance of Clusters } & \multirow{3}{*}{$\begin{array}{l}\text { Chi } \\
\text { square }\end{array}$} & \multirow{3}{*}{ Probability } \\
\hline & & C1 & $\mathrm{C2}$ & $\mathbf{C 3}$ & $\mathrm{C4}$ & & \\
\hline & Size of cluster & 137 & 41 & 26 & 21 & & \\
\hline \multirow{3}{*}{ Growth traits } & Days to $50 \%$ flowering & 84.36 & 49.60 & 67.46 & 63.81 & 4.29 & 0.23 \\
\hline & Plant height $(\mathrm{cm})$ & 57.24 & 71.49 & 96.89 & 125.84 & 8.18 & 0.04 \\
\hline & Productive tillers plant $^{-1}$ & 1.64 & 3.46 & 31.16 & 1.53 & 155.20 & $<.0001$ \\
\hline \multirow{4}{*}{ Panicle traits } & Panicle length $(\mathrm{cm})$ & 1.44 & 1.69 & 1.99 & 1.87 & 1.62 & 0.65 \\
\hline & Spikelet panicle $^{-1}$ & 62.43 & 105.27 & 108.06 & 238.25 & 22.21 & $<.0001$ \\
\hline & Chaffy panicle ${ }^{-1}$ & 23.30 & 20.48 & 38.39 & 55.17 & 10.96 & 0.01 \\
\hline & Spikelet fertility (\%) & 16.69 & 26.45 & 31.24 & 14.32 & 7.62 & 0.05 \\
\hline \multirow{3}{*}{$\begin{array}{l}\text { Grain quality } \\
\text { traits }\end{array}$} & Grain length (mm) & 1.30 & 1.27 & 1.29 & 2.76 & 6.37 & 0.10 \\
\hline & Grain breadth (mm) & 0.16 & 0.21 & 0.13 & 0.21 & 2.22 & 0.53 \\
\hline & $\mathrm{L} / \mathrm{B}$ ratio & 0.40 & 0.62 & 0.91 & 1.11 & 16.78 & 0.00 \\
\hline \multirow{4}{*}{ Yield traits } & 1000 grain weight $(\mathrm{g})$ & 8.44 & 8.04 & 5.19 & 15.64 & 7.15 & 0.07 \\
\hline & Straw yield plant $^{-1}(\mathrm{~g})$ & 8.46 & 7.28 & 7.17 & 9.40 & 0.74 & 0.86 \\
\hline & Harvest index & 0.00 & 0.00 & 0.22 & 0.01 & 344.80 & $<.0001$ \\
\hline & Grain yield plant $^{-1}(\mathrm{~g})$ & 6.86 & 5.96 & 8.68 & 5.90 & 1.32 & 0.72 \\
\hline
\end{tabular}


Table.5 Traditional Rice Varieties with contrasting expression for selected traits

\begin{tabular}{|c|c|c|c|c|c|}
\hline Sl.No & Characters & 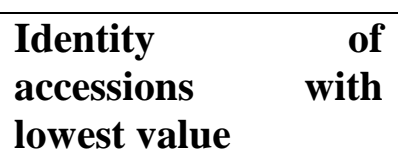 & $\begin{array}{l}\text { Mean } \\
\text { value }\end{array}$ & 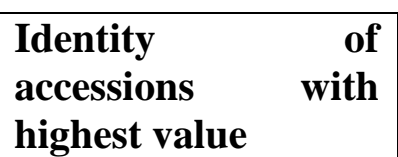 & $\begin{array}{l}\text { Mean } \\
\text { value }\end{array}$ \\
\hline \multirow{5}{*}{1} & \multirow{5}{*}{$\begin{array}{l}\text { Days to fifty } \\
\% \text { flowering }\end{array}$} & Tabandi sal & 71.75 & Anandi & 114.75 \\
\hline & & Dani sal & 73.00 & Gowrisanna & 115.50 \\
\hline & & Jeervel & 74.25 & Gowrisanna & 115.75 \\
\hline & & Rahodaya & 74.75 & Kaggali kervana & 115.75 \\
\hline & & Chinna pooni & 75.25 & Manila & 115.75 \\
\hline \multirow{5}{*}{2} & \multirow{5}{*}{$\begin{array}{l}\text { Spikelet } \\
\text { fertility }(\%)\end{array}$} & Anekombu batta & 59.58 & Navara & 85.96 \\
\hline & & Kali katesi & 61.18 & Malkod & 86.47 \\
\hline & & Kempudadde gida & 62.90 & Guddani & 86.52 \\
\hline & & Anandi & 65.04 & Adikane & 86.56 \\
\hline & & Dodda alur & 65.67 & Kartha & 87.83 \\
\hline \multirow{5}{*}{3} & \multirow{5}{*}{$\begin{array}{l}1000 \text { grain } \\
\text { weight }(\mathrm{g})\end{array}$} & Bilikanna Hegge & 14.87 & Dodda batta & 29.06 \\
\hline & & Jeerige sanna & 14.95 & Sampoge & 29.27 \\
\hline & & Gandha Sale & 15.55 & Andra basumati & 29.65 \\
\hline & & Theertha halli local & 16.21 & Tiruvani & 30.25 \\
\hline & & Gowrisanna & 16.86 & Malkod & 30.28 \\
\hline \multirow{5}{*}{4} & \multirow{5}{*}{$\begin{array}{l}\text { Straw yield } \\
\text { plant }^{-1}\end{array}$} & Kari Swarna & 8.85 & Rajboga & 23.28 \\
\hline & & Sampoge & 9.31 & Coimbathour & 23.71 \\
\hline & & Sanna mallige & 9.37 & K.N. local & 24.39 \\
\hline & & Nagabatta & 10.09 & Toranada batta & 24.70 \\
\hline & & Gandha Sale & 10.10 & Bangara Sanna & 27.03 \\
\hline \multirow{5}{*}{5} & \multirow{5}{*}{$\begin{array}{l}\text { Harvest } \\
\text { index }\end{array}$} & Bilidoddi & 0.33 & Ramgali & 0.60 \\
\hline & & Kali katesi & 0.33 & Kaduvelpe & 0.60 \\
\hline & & Bigan manji & 0.34 & Kundi pullan & 0.61 \\
\hline & & Toranada batta & 0.35 & Nagabatta & 0.62 \\
\hline & & Kalajeera & 0.36 & Sampoge & 0.66 \\
\hline \multirow{5}{*}{6} & \multirow{5}{*}{$\begin{array}{l}\text { Grain yield } \\
\text { plant }^{-1}\end{array}$} & Kali katesi & 6.94 & Possugandhi & 19.57 \\
\hline & & Nirga samba & 7.30 & Kaduvelpe & 20.01 \\
\hline & & Kari Swarna & 7.86 & Bangara sanna & 20.11 \\
\hline & & Bigan manji & 7.87 & Kannur & 20.22 \\
\hline & & Kalajeera & 8.20 & Putta batta & 20.75 \\
\hline
\end{tabular}

Some of the TRVs were superior for six selected traits such as days to fifty per cent flowering, spikelet fertility, 1000 grain weight, straw yield, harvest index and grain yield/plant. The TRVs contrasting for these selected six traits were identified (Table 5). The TRVs such as Tabandi sal, Dani sal,
Jeervel, Rahodaya and Chinna pooni with fewer days to 50 per cent flowering, Navara, Malkod, Guddani, Adikane and Kartha with high spikelet fertility, Dodda batta, Sampoge, Andra basumati, Tiruvani and Malkod with high 1000 grain weight, Rajboga, Coimbathour, K.N. local, Toranada batta and 
Bangara Sanna with high straw yield, Ramgali, Kaduvelpe, Kundi pullan, Nagabatta and Sampoge with high harvest index, Kali katesi, Nirga samba, Kari Swarna, Bigan manji and Kalajeera for high grain yield was identified. These TRVs are useful for developing populations for mapping genes controlling all these traits simultaneously.

\section{References}

Brush, S., Meng, E. 1998. Farmers' valuation and conservation of crop genetic resources. Genet. Res. Crop Evol., 45: $139-150$.

FAO. 1998. The state of the world's plant genetic resources for food and agriculture. United Nations Food and Agriculture Organization (FAO), Rome, Italy.

FAO. 1998. The state of the world's plant genetic resources for food and agriculture. United Nations Food and Agriculture Organization (FAO), Rome, Italy.

Ganapathy, S., Ganesh, S.K., Vivekanandan, P., Shanmugasundaram, P. and Babu, R.C. 2007. Variability and interrelationship between yield and physiomorphological traits in rice (Oryza sativa L.) under moisture stress condition. Crop Res., 34(1/3): 260-262.

Gauchan, D., Smale, M.M.N. and Cole, M. 2006. Managing rice biodiversity onfarms: The choices of farmers and breeders in Nepal. In: Small M (ed) Valuing crop biodiversity: on-farm genetic resources, economic change. CABI Publishing, Wallingford, UK, pp 162-176.
Gyawali, S., Sthapit, B.R., Bhandari, B., Bajracharya, J., Shrestha, P.K., Upadhyay, M.P. and Jarvis, D.I. 2010. Participatory crop improvement and formal release of Jethobudho rice landrace in Nepal. Euphytica, 176: 59-78.

Hanamaratti, N.G., Prashanthi, S.K., Salimath, P.M., Hanchinal, R.R., Mohankumar, H.D., Parameshwarappa, K.G. and Raikar, S.D. 2008. Traditional land races of rice in Karnataka: Reservoirs of Valuble traits. Curr. Sci., 94(2): 242-247.

Karim, D., Sarkar, U., Siddique, M.N.A., Khaleque Miah, M.A. and Hasnat, M.Z. 2007. Variability and genetic parameter analysis in aromatic rice. Int. J. Sustain. Crop Prod., 2(5):15-18.

Levene, H. 1960. Robust tests for equality of variances. In: Olkin et al., (ed.). Contributions to probability and statistics: Essays in honour of Harold Hotelling. Stanford University Press, Stanford pp: 278-292.

Macqueen, J. 1967. Some methods for classification and analysis of multivariate observations, Fifth Berkeley Symposium, pp. 281-297.

Mall, A.K., Babu, J.D.P. and Babu, G.S. 2005. Estimation of genetic variability in rice. $J$. Maharashtra Agril. Univ., 30(2): 166168.

Smale, M. 2006. valuing crop biodiversity: onfarm genetic resources and economic change. CABI Publishing, Wallingford, UK, pp no: $1-4$.

Snedecor, G.W. and Cochran, W.G. 1994. Statistical methods. $8^{\text {th }}$ edition, Iowa state university press, Ames, Iowa, USA.

\section{How to cite this article:}

Nandini, B., E. Gangappa, M.P. Rajanna, P. Mahadevu, S. Ramesh and Shailaja Hittalmani, P.V. 2017. Genetic Variability Analysis for Grain Yield and its Components Traits in Traditional Rice Varieties (TRVs). Int.J.Curr.Microbiol.App.Sci. 6(8): 494-502. doi: https://doi.org/10.20546/ijcmas.2017.608.064 